\title{
Mengefektifkan Supervisi Akademik Di SD Negeri 25 Ampenan Semester Dua Tahun Pelajaran 2017/2018 Dalam Upaya Meningkatkan Kompetensi Guru Dalam Proses Pembelajaran Di Kelas
}

\author{
Rahmatullaily \\ Kepala SD Negeri 25 Ampenan
}

\begin{abstract}
Abstrak; Yang melatar belakangi diadakannya Penelitian Tindakan Sekolah (PTS) ini yaitu rendahnya kompetensi Guru Kelas dalam proses pembelajaran di kelas. Solusinya yaitu dengan mengefektifkan pelaksanaan supervisi akademik. Permasalahannya apakah pelaksanaan supervisi akademik dapat meningkatkan kompetensi guru dalam proses pembelajaran di kelas Semester dua tahun Pelajaran 2017/2018 di SD Negeri 25 Ampenan. Tujuan penelitian ini adalah untuk mengetahui efektifitas pelaksanaan supervisi akademik dalam upaya meningkatkan kompetensi Guru Kelas dalam pembelajaran di kelas, yang manfaatnya bagi kepala sekolah adalah untuk mengetahui peningkatan kompetensi guru dalam proses pembelajaran. Penelitian ini dilaksanakan selama dua siklus, masing-masing siklus kegiatannya ada empat tahapan yaitu perencanaan, pelaksanaan, observasi, dan refleksi. Indikator keberhasilan dalam penelitian ini adalah; 1) hasil observasi kepala Sekolah maupun observasi guru selama proses pendampingan telah memperoleh skor rata-rata $\geq 4,0,2)$ hasil akhir $>85 \%$ dari jumlah peserta pendampingan memperoleh nilai ratarata $\geq 80,00$ (kategori baik). Pada siklus II observasi kepala Sekolah rata-rata $(4,60)$, observasi guru rata-rata $(4,33)$ dan hasil supervisi akademik di sasaran rata-rata nilai $(84,38)$. Indikator keberhasilan telah tercapai, penelitian di nyatakan berhasil dan dihentikan pada siklus II. Kesimpulan; Hasil penelitian pada siklus ke 2 menunjukkan peningkatan kompetensi Guru dalam proses pembelajaran di kelas senyatanya. Disarankan agar Kepala Sekolah lainnya melakukan penelitian sejenis dalam upaya peningkatan kompetensi guru, dan kepada guru kelas sejenis agar melakukan proses pembelajaran sesuai dengan skenario yang telah direncanakan dengan baik, tanggung jawab, bersunggung-sungguh demi peningkatan prestasi belajar peserta didik sesuai dengan bidang studi/mata pelajaran yang menjadi tanggung jawabnya.
\end{abstract}

Kata kunci : Supervisi akademis - kompetensi Guru

\section{PENDAHULUAN}

Peran Kepala Sekolah sangat penting dalam upaya meningkatkan kepedulian guru sebagai tenaga pendidik utamanya dalam merancang skenario pembelajaran dan dalam pelaksanaannya di kelas senyatanya. Oleh karena itu sangat diperlukan sosok Kepala Sekolah yang bisamengayomi serta mampu menjadi panutan/keteladanan bagi semua guru yang menjadi tanggung jawabnya. Untuk memenuhi harapan ini Kepala Sekolah perlu melakukan pembinaan, pembimbingan kepada semua guru dalam menyusun rancangan pembelajaran serta mengawasi pelaksanaan pembelajaran di kelas secara terencana, terjadwaldan ada tindak lanjutnya.

Berdasarkan hasil pemantauan kepala SD Negeri 25 Ampenan sebelum diadakan tindakan di jumpai bahwa cara mengajar guru kelas maupun guru bidang studi masih belum sepenuhnya sesuai dengan pendekatan saintifik; 1) guru kelas I kecendrungan mengajar dengan ceramah dan menyanyi saja, 2) guru kelas II juga masih sama yaitu dengan metode ceramah dan bernyanyi, 3) guru kelas III masih kecendrungan mengajar dengan ceramah dan pemberian tugas, 4) guru kelas IV masih tetap dengan ceramah yang dipadukan dengan pemberian tugas sama halnya dengan guru kelas III, 5) guru kelas V juga masih di dominasi dengan ceramah, penugasan, dan sesekali diskusi kelompok, dan 6) guru kelas VI kondisinya tidak jauh berbeda dengan cara mengajar guru kelas $\mathrm{V}$ yaitu ceramah, penugasan, dan diskusi kelompok. Kesimpulannya adalah bahwa kebanyakan guru SD Negeri 25 Ampenan mengajar dengan mengedepankan ceramah 
saja. Padahal tuntunan kurikulum 2013 tidaklah demikian. Pendekatan saintifik mengisyaratkan bahwa dalam proses pembelajaran di kelas langkah pembelajarannya ada 5 (lima) yaitu mengamati (observing), menanya (questioning), mengumpulkan informasi/mencoba (Experimenting), menalar/mengasosiasi (associating), dan yang kelima adalah mengkomunikasikan (comunicating). Dan di SD Negeri 25 Ampenan masih ada 2 (dua) kelas yang menggunakan KTSP yaitu kelas III dan kelas V.

Ada beberapa penyebab mengapa kebanyakan guru SD Negeri 25 Ampenan mengajar masih cenderung menggunakan pola ceramah (guru sentris) yaitu; 1) kebanyakan guru beranggapan bahwa ceramah sangat mudah dilakukan tanpa perencanaan terlebih dulu, 2) ceramah dapat menyelesaikan materi pelajaran dan tujuan pembelajaran, 3) ceramah bisa membuat guru merupakan satu-satunya sumber belajar dengan menghadap ke arah guru dan mendengarkan apa yang menjadi keinginan guru serta menghiraukan keinginan dan pendapat dari peserta didik.

Banyak soulsi yang bisa dilakukan oleh kepala SD Negeri 25 Ampenan selaku peneliti misalnya dengan mengefektifkan kegiatan KKG, mikro teaching/riil teaching, workshop, diklat, dan yang paling tepat adalah mengoptimalkan pelaksanaan supervisi akademik bagi guru SD Negeri 25 Ampenan secara terencana, terprogram, dan terbimbing. Dengan demikian dari banyaknya alternatif solusi yang dilakukan oleh peneliti, yang dianggap tepat dan bisa mewakili dari beberap solusi yang telah disebutkan yaitu dengan "mengefektifkan pelaksanaan supervisi akademik bagi guru kelas di SD Negeri 25 Ampenan semester dua tahun pelajaran 2017/2018. Ada beberapa kelebihan dengan mengefektifkan pelaksanaan supervisi akademik, yaitu; 1) mampu menyentuh karakter pendidik sehingga bisa merubah mindset cara mengajar guru dari pola pembelajaran guru sentris ke pola pembelajaran peserta didik aktif, 2) dapat meningkatkan profesionalisme guru sehingga menjadi guru yang profesional di bidang proses pembelajaran di kelas senyatanya, dan 3) mampu meningkatkan hasil belajar dan prestasi belajar peserta didik.

Untuk membuktikan akan kelebihan supervisi akademik maka perlu diadakan Penelitian Tindakan Sekolah (PTS) dengan alasan; 1) apabila supervisi aakdemik dilaksanakan secara terencana, terjadwal dan konsisten maka kompetensi guru dalam proses pembelajaran dapat ditingkatkan, 2) guru akan mengeluarkan jurus terbaiknya dalam melaksanakan proses pembelajaran di kelas senyatanya yang mengarah ke peserta didik aktif, inofatif, kreatif, efektif, dan menyenangkan (PAIKEM), 3) proses pembelajaran bisa berjalan efektif, dan menghasilkan produk peserta didik yang berkualitas yang dibuktikan dengan meningkatnya hasil belajar dan prestasi belajar. Adapun judul Penelitian Tindakan Sekolah (PTS) yang diangkat adalah; "Mengefektifkan Supervisi Akademik Di SD Negeri 25 Ampenan Semester Dua Tahun Pelajaran 2017/2018 Dalam Upaya Meningkatkan Kompetensi Guru Dalam Proses Pembelajaran Di Kelas."

\section{Rumusan Masalah}

"apakah supervisi akademik dapat meningkatkan kompetensi guru dalam proses pembelajaran Semester dua tahun pelajaran 2017/2018 di SD Negeri 25 Ampenan?"

\section{Tujuan Penelitian}

"Untuk mengetahui efektifitas pelaksanaan supervisi akademik dalam proses pembelajaran di kelas senyatanya, upaya meningkatkan kompetensi guru kelas semester dua tahun pelajaran 2017/2018 di SD Negeri 25 Ampenan."

\section{Manfaat Penelitian}

1. Bagi Kepala Sekolah, sangat bermanfaat dalam rangka melaksanakan pembimbingan bagi guru kelaas di sekolah binaannya khususnya tentang tata cara mengajar yang baik dan benar berdasarkan kurikulum 2013 melalui kegiatan supervisi akademik.

2. Bagi guru, sangat bermanfaat dalam upaya meningkatkan kompetensi dalam proses 
pembelajaran di kelas senyatanya sehingga bisa menjadi guru yang profesional dan mampu mengajar peserta didik dengan skenario yang telah ditetapkan pada Rencana Pelaksanaan Pembelajaran (RPP).

\section{KAJIAN PUSTAKA}

\section{KONSEP SUPERVISI AKADEMIK}

Salah satu tugas Kepala sekolah/madrasah adalah melaksanakan supervisi akademik. Untuk melaksanakan supervisi akademik secara efektif diperlukan keterampilan konseptual, interpersonal dan teknikal (Glickman, at al. 2007). Oleh sebab itu, setiap Kepala sekolah/madrasah harus memiliki dan menguasai konsep supervisi akademik yang meliputi: pengertian, tujuan dan fungsi, prinsip-prinsip, dan dimensidimensi substansi supervisi akademik. Supervisi akademik yang dilakukan Kepala sekolah/madrasah antara lain adalah sebagai berikut: (1) Memahami konsep, prinsip, teori dasar, karakteristik, dan kecenderungan perkembangan tiap bidang pengembangan pembelajaran kreatif, inovatif, pemecahan masalah, berpikir kritis dan naluri kewirausahaan, (2) Membimbing guru dalam menyusun silabus tiap bidang pengembangan di sekolah/madrasah atau mata pelajaran di sekolah/madrasah berlandaskan standar isi, standar kompetensi dan kompetensi dasar, dan prinsip-prinsip pengembangan Kurikulum 2013 dan KTSP, (3) Membimbing guru dalam memilih dan menggunakan strategi/ metode/teknik pembelajaran/bimbingan yang dapat mengembangkan berbagai potensi siswa, (4) Membimbing guru dalam melaksanakan kegiatan pembelajaran/ bimbingan (di kelas, laboratorium, dan/atau di lapangan) untuk mengembangkan potensi siswa, (5) Membimbing guru dalam mengelola, merawat, mengembangkan dan menggunakan media pendidikan dan fasilitas pembelajaran, (6) Memotivasi guru untuk memanfaatkan teknologi informasi untuk pembelajaran.

Kompetensi supervisi akademik intinya adalah membina guru dalam meningkatkan mutu proses pembelajaran. Sasaran supervisi akademik adalah guru dalam melaksanakan proses pembelajaran, yang terdiri dari materi pokok dalam proses pembelajaran, penyusunan silabus dan RPP, pemilihan strategi/metode/teknik pembelajaran, penggunaan media dan teknologi informasi dalam pembelajaran, menilai proses dan hasil pembelajaran serta penelitian tindakan kelas. Oleh karena itu, materi ini diharapkan dapat memberikan wawasan kepada Kepala Sekolah dalam meningkatkan kompetensi supervisi akademik yang meliputi: (1) memahami konsep supervisi akademik, (2) membuat rencana program supervisi akademik, (3) menerapkan teknik-teknik supervisi akademik, menerapkan supervisi klinis, dan (5) melaksanakan tindak lanjut supervisi akademik.

Tujuan supervisi akademik adalah: (1) membantu guru mengembangkan kompetensinya, (2) mengembangkan kurikulum, (3) mengembangkan kelompok kerja guru, dan membimbing penelitian tindakan kelas (PTK) (Glickman, et al. 2007, Sergiovanni, 1987). Supervisi akademik merupakan salah satu (fungsi mendasar (essential function) dalam keseluruhan program sekolah (Weingartner, 1973; Alfonso dkk., 1981; dan Glickman, et al. 2007 dalam https://www.academia.edu/6747/supervisi_ak ademik_oleh_kepala_sekolah)). Hasil supervisi akademik berfungsi sebagai sumber informasi bagi pengembangan profesionalisme guru.

\section{PERENCANAAN SUPERVISI AKADEMIK}

PROGRAM

Salah satu tugas Kepala sekolah adalah merencanakan supervisi akademik. Agar Kepala sekolah dapat melaksanakan tugasnya dengan baik, maka Kepala sekolah harus memiliki kompetensi membuat rencana program supervisi akademik. Perencanaan program supervisi akademik adalah penyusunan dokumen perencanaan pelaksanaan dan perencanaan pemantauan dalam rangka membantu guru mengembangkan kemampuan mengelola proses pembelajaran untuk mencapai tujuan pembelajaran.

Manfaat perencanaan program supervisi akademik adalah sebagai berikut: 
(1) Sebagai pedoman pelaksanaan dan Kepalaan akademik, (2) Untuk menyamakan persepsi seluruh warga sekolah tentang program supervisi akademik, (3) Penjamin penghematan serta keefektifan penggunaan sumber daya sekolah (tenaga, waktu dan biaya). Prinsip-prinsip perencanaan program supervisi akademik adalah: (1) objektif (data apa adanya), (2) bertanggung jawab, (3) berkelanjutan, (4) didasarkan pada Standar Nasional Pendidikan, dan (5) didasarkan pada kebutuhan dan kondisi sekolah/madrasah.

\section{TEKNIK-TEKNIK} AKADEMIK

SUPERVISI

Satu di antara tugas Kepala sekolah adalah melaksanakan supervisi akademik. Untuk melaksanakan supervisi akademik secara efektif diperlukan keterampilan konseptual, interpersonal dan teknikal (Glickman, at al. 2007). Oleh sebab itu, setiap Kepala sekolah harus memiliki keterampilan teknikal berupa kemampuan menerapkan teknik-teknik supervisi yang tepat dalam melaksanakan supervisi akademik. Teknik-teknik supervisi akademik meliputi dua macam, yaitu: individual dan kelompok (Gwyn, 1961).

Teknik supervisi akademik ada dua yaitu: individual dan kelompok.

\section{KOMPETENSI GURU}

Untuk memberikan pengertian dan pemahaman tentang kompetensi guru, akan diuraikan terlebih dahulu pengertian kompetensi secara umum. Kompetensi berasal dari kata competency yang berarti yang berarti kemampuan atau kecakapan. Menurut kamus besar Bahasa Indonesia, kompetensi dapat diartikan (kewenangan) kekuasaan untuk menentukan atau memutuskan satu hal. Istilah kompetensi memiliki banyak makna dan pengertian diantaranya adalah sebagai berikut:

Yang dimaksud kompetensi guru dalam penelitian ini adalah kemampuan dan ketrampilan ke 6 (enam) guru kelas SD Negeri 25 Ampenan dalam proses pembelajaran di kelas senyatanya. Kompetensi yang dimaksud adalah kemampuan dan ketrampilan dalam menerapkan pendekatan, strategi, dan metode pembelajaran sesuai dengan Rencana Pelaksanaan Pembelajaran (RPP) yang telah di siapkan.

\section{Hipotesis Tindakan}

"pelaksanaan supervisi akademik dapat meningkatkan kompetensi guru kelas SD Negeri 25 Ampenan dalam proses pembelajaran berdasarkan kurikulum 2013 di kelas semester dua tahun pelajaran 2017/2018"

\section{PROSEDUR PENELITIAN}

\section{Jenis Penelitian}

\section{Setting Penelitian}

Penelitian Tindakan Sekolah (PTS) ini dilaksanakan di SD Negeri 25 Ampenan dengan mengefektifkan pelaksanaan supervisi akademik bagi enam orang guru kelas.

Jenis Tindakan dan dampak yang diharapkan

a. Jenis Tindakan : supervisi akademik dalam proses pembelajaran di kelas senyatanya

b. Dampak yang diharapkan : meningkatkan kompetensi pedagogik guru kelas SD Negeri 25 Ampenan dalam melaksanakan proses pembelajaran di kelas senyatanya.

\section{Perencanaan Tindakan}

\section{Jenis tindakan yang dilakukan}

a) Kepala Sekolah menyampaikan hasil pemantauan terhadap 6 (enam) guru kelas dalam proses pembelajaran di kelas ditemukan masih mengalami kendala.

b) Kepala Sekolah menyampaikan materi pendampingan yang terfokus pada tata cara mengajar yang baik dan benar berdasarkan kurikulum 2013.

\section{Skenario Supervisi Akademik}

Skenario supervisi akademik dalam penelitian ini adalah, langkah yang diambil pada kegiatan supervisi akademik dengan mengumpulkan 6 (enam) guru kelas SD Negeri 25 Ampenan untuk diberikan penjelasanan tentang supervisi akademik yang difokuskan pada kegiatan pembelajaran dikelas senyatanya. Untuk mendapatkan gambaran yang jelas tentang skenario pelaksanaan tindakan dalam kegiatan supervisi akademik ini dapat digambarkan sebagai berikut: 


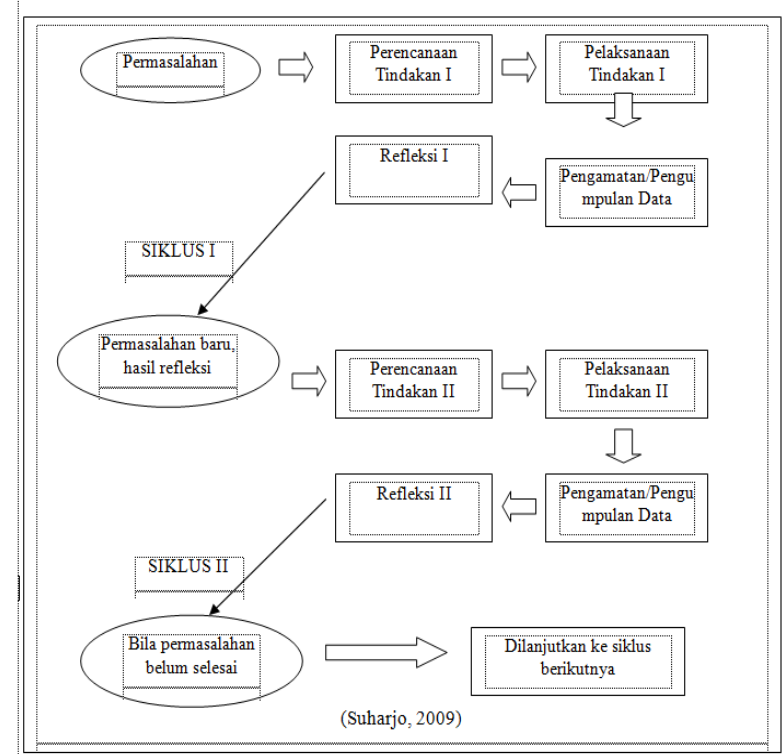

\section{Pelaksanaan Tindakan}

Dalam penelitian ini peneliti melakukan supervisi akademik yang terfokus pada pelaksanaan proses pembelajaran di kelas senyatanya. Jenis instrumen yang digunakan dalam penelitian ini sebagai berikut:

1. Instrumen pengamatan/observasi Kepala sekolah yang dilakukan oleh Pengawas pembimbing selaku observers

2. Instrumen pengamatan/observasi guru selama kegiatan penjelasan teknik dilakukan oleh Kepala sekolah sekaligus sebagai peneliti.

3. Instrumen penilaian hasil kerja individual dalam proses pembelajaran di kelas dilakukan oleh peneliti, ini sekaligus sebagai tolak ukur keberhasilan selama supervisi akademik sesuai indikator kinerja yang telah ditetapkan.

\section{Evaluasi dan Refleksi Tindakan}

Adapun kegiatan riilnya adalah : 1) membandingkan hasil pengamatan aktifitas dari ke 6 (enam) guru kelas selama proses bimbingan selama supervisi akademik, 2) membandingkan perolehan nilai hasil kegiatan pembelajaran di kelas senyatanya dengan indikator keberhasilan yang telah ditetapkan.

\section{SIKLUS TINDAKAN}

\section{SIKLUS I}

\section{Tahap I : Perencanaan Tindakan}

1. Menyusun materi tentang supervisi akademik
2. Menetapkan skneario dan langkah-langkah pendampingan

3. Menyusun instrumen observasi Kepala sekolah dan observasi guru

4. Menentukan jadwal kegiatan supervisi akademik

5. Menyusun pedoman analisa data hasil observasi dan hasil supervisi akademik

Tahap II : Pelaksanaan Tindakan

a) Kegiatan pendampingan

1. Menyampaikan materi tentang tata cara mengajar yang baik dan benar

2. Melaksanakan tanya jawab tentang tata cara mengajar yang baik dan benar

3. Memberikan bimbingan terhadap peserta yang mengalami kesulitan

4. Memberikan solusi terhadap permasalahan yang dihadapi guru

5. Memberikan penguatan/reward

6. Memberikan tugas individual

b) Kegiatan supervisi akademik

Secara terjadwal dan bergiliran peneliti melakukan supervisi akademik di kelas tempat guru mengajar

Tahap III : Pengamatan/pengumpulan Data

1. Pengamatan terhadap aktifitas guru selama pembimbingan

2. Pengamatan terhadap guru dalam proses pembelajaran (supervisi akademik)

3. Menilai hasil tampilan guru selama proses pembelajaran di kelas

Tahap IV : Refleksi

1. Renungan atas data hasil observasi dan hasil penilaian selama proses pembelajaran di kelas

2. Pengolahan data hasil penelitian dan mencocokkan dengan indikator keberhasilan

3. Rencana perbaikan dan penyempurnaan

4. Memberikan penguatan atas hasil yang diperolehnya.

5. Rencana tindak lanjut

\section{SIKLUS II}

Jenis kegiatan pada siklus II ini pada dasarnya sama dengan siklus I, bedanya hanya terjadi perbaikan/penyempurnaan dalam pelaksanaannya. 


\section{Indikator Keberhasilan}

1. Hasil observasi Kepala sekolah maupun observasi guru selama proses pendampingan telah memperoleh skor rata-rata $\geq 4,0$ (kategori baik/kategori aktif)

2. Kompetensi pedagogik dalam proses pembelajaran dinyatakan berhasil jika $\geq$ 85\% dari jumlah guru kelas memperoleh nilai rata-rata $\geq 80,00$ (kategori baik).

\section{LAPORAN HASIL DAN PEMBAHASAN SIKLUS I}

Tahap Perencanaan

Pada tahapan ini peneliti telah berhasil: 1) menyusun materi tentang supervisi akademik, 2) menetapkan skenario dan langkah-langkah pendampingan, 3) menyusun instrumen observasi Kepala sekolah observasi guru, dan instrumen kegiatan supervisi akademik, 4) menentukan jadwal kegiatan supervisi akademik yang terbagi menjadi 2 (dua) pertemuan, 5) menyusun pedoman analisa data hasil observasi dan hasil supervisi akademik,

\section{Tahap Pelaksanaan}

Pada tahapan ini peneliti melakukan 2 (dua) kegiatan yaitu kegiatan pendampingan/pembimbingan secara klasikal, dan kegiatan kedua adalah pelaksanaan supervisi akademik di kelas senyatanya.

\section{Tahap Pengumpulan/Pengumpulan Data}

Observasi kepala sekolah memperoleh skor rata-rata sebesar 3,30, observasi guru memperoleh skor rata-rata sebesar 3,33, dan hasil supervise akademik dikelas memperoleh nilai rata-rata sebesar 66,11

\section{Tahap Refleksi}

Pada tahap ini peneliti melakukan beberapa kegiatan yang merupakan tahapan akhir dari pelaksanaan siklus I, yaitu kegiatan perencanaan, pelaksanaan, dan observasi. Adapun kegiatan secara rinci meliputi: 1) renungan atas data hasil observasi dan hasil pengamatan selama proses pembelajaran di kelas senyatanya, 2) pengolahan data hasil penelitian dan mencocokkan dengan indikator keberhasilan, 3) rencana perbaikan dan penyempurnaan, 4) memberikan penguatan atas hasil yang diperolehnya, dan 5) rencana tindak lanjut.

\section{SIKLUS II}

Tahap Perencanaan

Pada tahapan ini peneliti kegiatannya masih mengacu pada siklus I yakni merencanakan: 1) penyusunan materi tentang supervisi akademik, 2) menetapkan skenario dan langkah-langkah pendampingan, 3) menyusun instrumen observasi Kepala sekolah dan observasi guru, 4) menentukan jadwal kegiatan supervisi akademik, 5) menyusun pedoman analisa data hasil observasi dan hasil supervisi akademik.

\section{Tahap Pelaksanaan}

Pada tahapan ini peneliti kegiatannya adalah masih sama dengan siklus I, bedanya pada siklus II ini pelaksanaannya lebih dioptimalkan karena kesalahan-kesalahan dan kekurangan pada siklus I sudah di deteksi dan sudah dicari jalan keluarnya.

\section{Tahap Pengamatan/Pengumpulan Data}

Observasi kepala sekolah memperoleh skor rata-rata sebesar 4,60, observasi guru memperoleh skor rata-rata sebesar 4,33, dan hasil supervise akademik dikelas memperoleh nilai rata-rata sebesar 84,38

\section{Tahap Refleksi}

Pada tahapan ini peneliti melakukan kegiatan penyempurnaan terhadap kesalahankesalahan yang terjadi pada siklus I. Adapum untuk kegiatannya adalah: 1) renungan atas data hasil observasi Kepala sekolah dan guru serta hasil supervisi akademik di kelas, 2) pengolahan data hasil penelitian dan mencocokkan dengan indikator kinerja, 3) rencana perbaikan dan penyempurnaan, 4) memberikan penguatan atas hasil yang diperolehnya, dan 5) rencana tindak lanjut.

\section{PEMBAHASAN}

\section{SIKLUS I}

\section{Tahap Perencanaan}

Dalam tahapan ini ada beberapa tahapan yang dilakukan diantaranya penyusunan materi tentang supervisi akademik, persiapan skenario tindakan selama pendampingan klasikal, penyusunan instrumen observasi Kepala sekolah dan instrumen observasi peserta pendampingan, penentuan jadwal supervisi akademik bagi 6 (enam) guru kelas dalam proses pembelajaran di kelas senyatanya, menentukan penyusunan 
pedoman analisa data hasil observasi Kepala sekolah, observasi guru dalam proses pembelajaran di kelas dan hasil supervisi akademik dari ke 6 (enam) guru kelas. Kegiatan ini mengalami beberapa kendala, tetapi setelah berkonsultasi dan meminta petunjuk dari pembimbing, kegiatan pun berjalan dengan lancar.

\section{Tahap Pelaksanaan}

Dalam melaksanakan pendampingan klasikal tentang perlunya pendampingan dan penyampaian materi tentang supervisi akademik yang kegiatan nyatanya menjelaskan bagaimana cara mengajar yang baik dan benar sesuai dengan instrumen yang telah ditetapkan. Pelaksanaan supervisi akademik dalam proses pembelajaran upaya meningkatkan kompetensi bagi guru kelas di mulai pada hari senin - Kamis, sesuai jadwal yang telah disepakati bersama.

\section{Tahap Pengamatan/Pengumpulan Data}

Hasil skor rata-rata yang diraih oleh Kepala sekolah/peneliti $(3,30)$ kategori cukup dari indikator keberhasilan yang diharapkan yaitu $\geq 4,00$ (kategori aktif). Sementara itu hasil observasi guru oleh peneliti selama proses pendampingan klasikal, dilihat dari aktifitas dari ke enam guru kelas memperoleh rata-rata $(3,33)$ kategori cukup dari indikator keberhasilan yang direncanakan yaitu $\geq 4,00$ (kategori aktif). Perolehan nilai rata-rata hasil supervisi akademik dari 6 (enam) guru kelas diperoleh hasil $(66,11)$ dengan presentase ketuntasan 0\%, Tahap Refleksi

Setelah semua perolehan data dianalisis dan di cocokkan dengan indikator keberhasilan, diperoleh data sebagai berikut: Hasil Observasi Kepala Sekolah $(3,30)$, Hasil Observasi Guru $(3,33)$ dan Hasil Supervisi Akademik $(66,11)$

\section{SIKLUS II}

\section{Tahap Perencanaan}

Pada tahapan ini peneliti melaksanakan kegiatan seperti halnya pada siklus I yaitu: 1) penyusunan materi pendampingan masih ada kendala yaitu materi yang disajikan masih sama dengan materi siklus I, faktor penyebabnya peneliti masih belum memahami materi apa lagi yang harus disusun, solusinya peneliti meminta petunjuk kepada pengawas pembimbing untuk mendapatkan solusi, setelah diberikan pengarahan akhirnya materi pendampingan dapat di buat lebih simpel dan lebih praktis sehingga guru tidak mengalami kesulitan dalam memahami materi tentang cara cara mengajar yang baik dan benar berdasarkan kurikulum 2013 dan KTSP, 2) penyusunan skenario tindakan yang sudah dibuat pada siklus I ditetapkan karena dianggap tidak ada kendala yang mengganggu kegiatan supervisi akademik, 3) penyusunan instrumen observasi kepala sekolah, observasi guru masih mengacu pada instrumen pada siklus I, 4) penentuan jadwal kegiatan juga tidak ada kendala, dan 5) penyusunan pedoman analisa data juga masih mengacu pada siklus I

\section{Tahap Pelaksanaan}

Peneliti melakukan pendampingan klasikal dengan mengoptimalkan tindakan nyata terutama kesalahankesalahan/kekurangan yang terjadi pada siklus I lebih dioptimalkan, sehingga dalam pelaksanaan pendampingan pada siklus II ini berjalan lancar tanpa hambatan yang berarti. Jadwal yang direncanakan dilaksanakan sesuai rencana dan tidak ada lagi guru yang terlambat dan kegiatan pendampingan berjalan tepat waktu. Semua guru aktif bertanya/tanya jawab yang menyebabkan suasana kekeluargaan semakin terjalin dengan erat dan menunjukkan etika yang sangat membanggakan. Ha-hal yang menjadi ganjalan pada siklus I dapat dipecahkan bersama-sama antara peneliti dengan guru kelas dalam mempersiapkan tahapan yang mutlak karena dikuasai oleh semua guru mata pelajaran yaitu proses pembelajaran di kelas senyatanya sesuai dengan skenario pembelajaran yang tertuang pada Rencana Pelaksanaan Pembelajaran (RPP). Pelaksanaan supervisi akademik di kelas senyatanya berjalan sesuai jadwal yang telah ditetapkan.

\section{Tahap Pengamatan/Pengumpulan Data}

Setelah semua perolehan data dianalisis dan di cocokkan dengan indikator keberhasilan, diperoleh data sebagai berikut: Hasil Observasi Kepala Sekolah (4,60), Hasil Observasi Guru (4,33) dan Hasil Supervisi 
Akademik $(84,38)$. Oleh karena itu penelitian dihentikan pada siklus II.

\section{Tahap Refleksi}

Hasil observasi Kepala sekolah, guru peserta pendampingan serta hasil supervisi akademik di kelas senyatanya sudah melebihi indikator keberhasilan yang telah ditetapkan. Penelitian Tindakan Sekolah (PTS) dinyatakan berhasil dan dihentikan pada siklus II.

Karena indikator keberhasilan sudah dapat tercapai maka penelitian Tindakan Sekolah (PTS) dinyatakan "BERHASIL" dan dapat dihentikan pada siklus ke II. Keberhasilan ini merupakan bukti nyata bahwa pelaksanaan supervisi akademik di SD Negeri 25 Ampenan pada semester dua tahun pelajaran 2017/2018 dapat meningkatan kompetensi guru kelas dalam proses pembelajaran di kelas senyatanya.

\section{KESIMPULAN DAN SARAN}

\section{Kesimpulan}

Pelaksanaan supervisi akademik dalam proses pembelajaran di kelas senyatanya dapat meningkatkan kompetensi guru kelas dalam melaksanakan pembelajaran di kelas berdasarkan kurikulum 2013 semester dua tahun pelajaran 2017/2018 di SD Negeri 25 Ampenan. Hal ini dapat dibuktikan bahwa data dari siklus I, dan II. Secara berturut-turut mengalami peningkatan.

Data riil hasil tindakan selama 2 siklus dapat dipaparkan dengan jelas sebagai berikut:

\begin{tabular}{|c|l|c|c|c|c|}
\hline No & \multicolumn{1}{|c|}{ Jenis Kegiatan } & $\begin{array}{c}\text { Indikator } \\
\text { Keberhasilan }\end{array}$ & $\begin{array}{c}\text { Siklus } \\
\text { I }\end{array}$ & $\begin{array}{c}\text { Siklus } \\
\text { II }\end{array}$ & Keterangan \\
\hline 1. & Hasil Observasi Kepala Sekolah & $\geq 4,00$ & 3,30 & 4,60 & Tuntas \\
\hline 2. & Hasil Observasi Guru & $\geq 4,00$ & 3,33 & 4,33 & Tuntas \\
\hline 3. & Hasil Supervisi Akademik & $\geq 80,00$ & 66,11 & 84,38 & Tuntas \\
\hline
\end{tabular}

\section{Saran}

a. Kepala Sekolah sejawat di lingkungan pembinaan Dinas Pendidikan Kota Mataram agar mencoba melakukan penelitian Tindaka Sekolah (PTS) dalam upaya meningkatkan kompetensi guru kelas dalam proses pembelajaran di kelas senyatanya melalui pelaksanaan supervisi akademik yang dilakukan secara terencana, terorganisir, dan penuh tanggung jawab sehingga mindset guru dalam pembelajaran di kelas dapat ditingkatkan. b. Kepada semua guru kelas dan guru bidang studi di SD Negeri 25 Ampenan disarankan agar senantiasa melakukan proses pembelajaran yang baik dan benar berdasarkan kurikulum 2013 dan KTSP sehingga hasil belajar dan prestasi belajar peserta didik dapat ditingkatkan dan KKM yang telah ditetapkan dapat tercapai bahkan dapat dilampaui.

\section{DAFTAR PUSTAKA}

alauddin, 2018. Supervisi Akademik Kepala Sekolah.

https://www.academia.edu/6747/SUPE RVISI_AKADEIK_OLEH_KEPALA SEKOLAH. diambil tanggal 11 Januari 2018. Pukul 09.36 wita.

Anonim, 2018, Aspek dan Kompetensi guru, dalam

https://akhmadsudrajat.wordpress.com/2 012/01/29/kompetensi-guru/, diambil tanggal 11 Januari 2018. Pukul 09.38 Wita

Alexander Mackie College of Advance Education. 1981. Supervision of Practice Teaching. Primary Program, Sydney, Australia.

Cahya Wirawan, 2012, Peningkatan Kompetensi Guru kelas Dalam Pemanfaatan Media Pembelajaran Melalui Mentoring, Jakarta: Jurnal PTK Dikmen

Dodd, W.A. 1972. Primary School Inspection in New Countries. London: Oxford University Press.

Glickman, C.D., Gordon, S.P., and RossGordon, J.M. 2007. Supervision and Instructional Leadership A Development Approach. Seventh Edition. Boston: Perason.

Gwynn, J.M. 1961. Theory and Practice of Supervision. New York: Dodd, Mead \& Company. Hamatih, 2006, Kurikulum Tingkat Satuan Pendidikan, Bandung: Remaja Rosda Karya.

Mantja, W. 1984. "Efektivitas Supervisi Klinik dalam Pembimbingan Praktek Mengajar Mahasiswa IKIP Malang,"Tesis. FPS IKIP Malang.

Mulyasa, 2007, Kurikulum Tingkat Satuan Pendidikan, Bandung: Remaja Rosda Karya. 
Nana Sujana, 2009, Pendidikan Tingkat KePenelitian Konsep Dan Aplikasinya Bagi Peneliti Sekolah, Jakarta: LPP Bina Mitra.

Peraturan Pemerintah Republik Indonesia Nomor 74 Tahun 2008 Tentang Guru

Permendikbud Nomor 103 Tahun 2014 tentang standar proses

Permendikbud Nomor 22 Tahun 2016 tentang standar proses

Robbins, S.P.2008. The Truth about Managing People. Second Edition. Upper Sadle River, New Jersey: Pearson Education, Inc.

Sergiovanni, T.J. 1982. Supervision of Teaching. Alexandria: Association for Supervision and Curriculum Development.

Suharjono, 2009, Melaksanakan Sekolah Sebagai Kegiatan Penelitian Tindakan Sekolah Sebagai Kegiatan Pengembangan Profesi Penelitia Sekolah, Jakarta: Bumi Aksara.

Sullivan, S. \& Glanz, J. 2005. Supervision that Improving Teaching Strategies and Techniques. Thousand Oaks, California: Corwin Press.

Sullivan, S \& Glanz, J. 2005. Supervision that ImprovesTeaching Strategies and Techniques. Thousand Oaks, California: Corwin Press.

Supervisi Akademik dalam peningkatan profesionalisme guru. 2006. Kompetensi Supervisi Kepala Sekolah Pendidikan Dasar. Direktorat Tenaga Kependidikan Ditjen PMPTK Depdiknas.

Undang-undang Nomor 20 Tahun 2003 Tentang Sistem Pendidikan Nasional Usman, 2005, Menjadi Guru Profesional, Bandung: Remaja Rosda Karya.

Wiles, J. dan J. Bondi. 1986. Supervision: A Guide to Practice . Second Edition. Columbus: Charles E. Merrill Publishing Company

Verma, V.K. 1996. The Human Aspects of Project Management Human Resources Skills for the Project Manager. Volume Two. Harper Darby,PA: Project Management Institute 